\title{
Reformatory schools and whiteness in danger: An Australian case
}

\author{
The Queensland Reformatory and Industrial Schools Act (1865) provided for the \\ creation of a system of reformatory and industrial schools. This paper explores the \\ early years of the reformatory for boys. The Act defined Aboriginal children as \\ 'neglected' and eligible to be sent to this institution. However, of the first thousand \\ children admitted, all but thirty-three were white. This paper explains this \\ contradiction by positioning the reformatory as a space in which fears about the \\ fragility of whiteness were enacted.
}

\section{Introduction}

The relationship between race and juvenile justice has a long and storied history. This paper explores the influence of whiteness, as both an ideal and a pathologised and fragile state of being, on practices relating to sentencing and reformation during the early years of a reformatory school in Queensland, Australia. In doing so, it highlights the way in which early juvenile justice in this context was tailored to promote the continuation of practices and ways of being associated with British whiteness. It also demonstrates the way in which children convicted of crime or perceived to be at risk of criminality were treated with a mix of techniques associated with protecting the whitenesss of children and that of adult men, thus highlighting the potential of class and criminality to undermine the status of children as children.

\section{Child removal and the reformatory}

As Lynch (2014) has demonstrated, child removal policies in Australia and other Western nations through the mid-nineteenth to mid-twentieth centuries were justified as projects of nation-building. Children in these contexts were valued not for themselves or because of the inherent value of childhood, but as future citizens. Removing children from environments deemed to be dangerous to their moral develop was a civic duty, a moral act, and an act of kindness. It was also a necessary preventative measure. Children who were removed were often seen as being in such danger of corruption that they posed a threat to the future of the community (2014: 179). The presence of child-saving and reformatory discourses in Australia arguably contributed to a fixation on Aboriginal children. The idea that children from populations perceived as dangerous could be reformed served to justify early child-removal policies (Robinson and Paten, 2008: 505).

As an Australian institution which participated in the removal of children, the reformatory must be understood in relation to histories of white Australians removing Indigenous children from their parents. Swain has noted that, in Australia, the term 'child removal' tends to refer solely to the removal of Indigenous children, obscuring the breadth of child removals that actually occurred and potentially implying that the removal of non-Indigenous children has been justified (2016: 191). While the removal of Indigenous children deserves to be understood in its specificity, she suggests that the decisions of courts relating to the removal of all children should be questioned and placed within the same historical narrative. This narrative demonstrates the importance of race, and the concept that children who could lay claim to a shared white heritage were more reformable than 
those who could not. The emphasis, in Indigenous child removal, on children with mixed heritage demonstrates the potency of this idea (Swain, 2016: 208).

Queensland's reformatory was influenced by those in England advocated by the social reformer and campaigner Mary Carpenter (1851). A noted advocate for reformatory institutions, Carpenter believed that all people, given the right education and opportunities, could become useful and productive members of society. In a sense a respect for all humankind was at the centre of her beliefs (Watts, 2001: 195). This attitude of respect was tempered by her belief in British superiority (2001: 206). This is a position which inflected the institutions she advocated. Carpenter believed that education alone could not improve the lot of children who were already in impoverished or criminal circumstances, not least because such children could not necessarily be persuaded to attend a free school. She believed that, nonetheless, all deviant children or those at risk must be subjected to the 'right training' in order to become useful members of society (1851: 347-348). Where this training could not be provided within the home environment, she advocated for the removal of children from their homes to boarding institutions.

Queensland's reformatory boys was created under the auspices of the Industrial and Reformatory Schools Act (Queensland, 1865). The Act provided for the creation of reformatory and industrial schools for both boys and girls. These schools would be boarding institutions, which would remove children from the influence of their family and the community around them. Children found guilty of criminal acts, or found by the courts to be neglected, could be sentenced to such institutions. As one glowing report in the Brisbane Courier put it:

Our object - and we believe that of the Colonial Secretary who has introduced the Industrial and Reformatory Schools Bill into Parliament is the same, - is to prevent the spreading of a social disease - to save from the gaol, children who, by being placed under proper supervision and being subjected to a certain amount of training and education, may become, in a few years, useful colonists (The Brisbane Courier, 1865: 2).

The government-operated reformatory which would eventuate from this legislation began its life in 1871 as the Reformatory School for Boys on the former prison hulk, Proserpine. This was no anomaly - ship hulks were used as reformatory schools in England, most notably Liverpool (Smith, 1998). In 1890 eleven ships housed either industrial or reformatory schools in England. However, these ships, which had the declared purpose of training children for the Navy, failed in this function (Hurt, 1984: 53). While the Queensland reformatory's first superintendent, James Wassell, believed that his reformatory boys could and should aspire to a life at sea, he was never very successful in ensuring this occurred (Savige, 1993). The institution then moved to the military barracks at Lytton before settling at its final home in Westbrook, where it operated, under various names, from 1900-1994 (Butterworth, 2014).

In its early days, this was an institution which had to bear an unexpected amount of pressure. A system of reformatory and industrial schools was initially proposed for Queensland. However, the only government institution which emerged to serve the needs of a broad population of boys who, through deviance, criminality, or destitution were seen as needing specific care and training in morality, was the reformatory which is the subject of this paper. A reformatory for girls was also established, and situated at Toowoomba. It is, to date, painfully under-researched, with only a few published works dealing with specific moments in its history (Carden, 2018; Savige, 1993). 
This study contributes to the limited literature on this institution by revealing its relationship to fears of racial degeneration in Queensland through the late nineteenth and early twentieth centuries. In doing so, it also contributes to a broader literature on reformatory institutions and childhood deviancy.

\section{Race and reformatory admissions}

This paper draws on, among other material, an analysis of the first 1,000 boys admitted to the institution between March 1871 and May 1900. The information obtained through this register provides a picture of the types of categories under which boys were admitted to the reformatory, their age, their religion, and the length of their sentences. It also provides information on the race of the children admitted. The register contains space for a description of the 'complexion', 'eye colour' and 'hair colour' of boys admitted. For white children these have been filled out with appropriate descriptors. However, children not classed as white simply have their race written across the space provided for this descriptive information. For this reason it is possible to ascertain that, of the first 1,000 boys admitted, only thirty-three were not white. Of these, four were described as 'Aboriginal,' another fourteen were described as 'Half caste,' and some other children had more descriptive racial markers ascribed to them, such as one boy described as 'Half caste Malay, mother Aboriginal.' At least five of these children were born outside of Australia and were not Aboriginal (Queensland State Archives Item ID532416, Register - admissions, 1871). Robinson and Paten have asserted that the record-keeping of Queensland's reformatories and orphanages was of such a low standard that it is impossible to ascertain how many Aboriginal children were sent to these institutions (2008: 511). It may well be the case that a full picture of the number of Aboriginal children removed to Queensland institutions is impossible to ascertain. However, the highly racialized practices of recording physical descriptions of the children admitted to the reformatory for boys suggests that, for the early admissions to this institution, a fairly accurate estimate can be made.

This overwhelming dominance of white children in this institution is out of line with the legislative conditions under which it operated. A child born to an Aboriginal mother could be sentenced to a reformatory as a neglected child on that basis alone (Queensland, 1865: 6). This provision made the Industrial and Reformatory Schools Act the first piece of legislation in Australia which allowed for the removal of Aboriginal children based only on their Aboriginality (Robinson and Paten, 2008: 508). In this context, where Aboriginal children were necessarily neglected children under the governing legislation, their low representation among the ranks of reformatory boys demands explanation.

I argue that this explanation may be obtained through an examination of the position of whiteness, as a concept and a state of being, in the Queensland of the late nineteenth and early twentieth centuries. Queensland, with its tropical and sub-tropical climates, represented a potential threat to the future of the white race. The reformatory was a space in which white boys who were engaged in deviant lifestyles, or who were seen as at risk of becoming engaged in such lifestyles, could be transformed into useful citizens. The remainder of this paper explores the racial fears associated with Queensland during this period, the ways in which they were addressed, and the extent to which they were reflected in the training offered by the reformatory for boys.

\section{Protecting whiteness in Queensland}

In colonial and early federation Australian nationhood and whiteness were inextricably bound. To be 
a strong and united nation was to be a white nation, one which had the capacity to continue British traditions. Whiteness, however, could not be taken for granted. It was not merely skin-deep. It was subject to degeneration and could only exist where the manners, beliefs, and lifestyles associated with British nationality could be continued. This attitude held a special significance for Queensland. The climate of Queensland's tropical north represented a new challenge. No white race, it was believed, had ever prospered in such an environment. Adapting to such a challenge required concerted efforts at education, including through formal schooling.

Whiteness was perceived as inherently fragile throughout Australia. Helen McDonald (2007) demonstrates that the fear of white Australia being overrun by non-white populations was evident in policies relating to the control of Indigenous Australians and the importation of white child migrants. The immigration of child migrants, although they came in relatively small numbers, helped to bolster the apparent strength of white Australia, while the removal of Aboriginal children and their sequestering in reserves served to differentiate white and non-white populations. McDonald demonstrates that legislation in Queensland relating to Aboriginal people and legislation relating to child welfare in England both served to facilitate the removal of children from their parents. Both groups were used as cheap, convenient, workforces in undesirable locations.

Queensland, however, was a special case. Robinson and Wilson (2008) have demonstrated that, from 1859 - 1918, white children in Queensland as a whole were seen as vital to the future of their race. At this point in Queensland's history the settlement of tropical - and to a lesser extent subtropical - geographical locales by a white population was viewed as an experiment. The school was an important space in which white children, considered so vital to the success of the Queensland experiment, could be trained, monitored, and shaped into the kind of citizens who would be able to survive and prosper in the Queensland climate.

In the context of education, whiteness was protected through practices seeking to inculcate health and hygiene. It has been argued that the focus on hygiene contributed to the positioning of whiteness as something more than mere colour (Bashford, 2000: 266). For example, JSC Elkington was a prominent figure in Australian public health at the turn of the twentieth century. From 1910, he was the Commissioner of Public Health in Queensland (Roe, 1981). His book, Health in the School (1907), speaks to a preoccupation with hygiene as an important aspect of Australian education. In that book he entreated teachers to take care to provide a learning environment that was clean and well-ventilated, and to instil a knowledge of cleanliness and hygienic practice in their pupils. Elkington, in a 1910 lecture, said that:

The first aim of education clearly is to fit the children of the nation as fully as possible for the work of life. During the process these children are not merely citizens-to-be, but are actually citizens. The after life for which they are being trained grows more and more artificial every year, and the standard for even moderate success rises ever higher as man's busy brain overcomes the impossible of to-day and fits it into to-morrow's daily round. Children must be taught to live as well as to work, for that very civilisation which demands so high a standard of fitness ruthlessly treads down the unfit. The need for a sound well-cared-for body is even greater than it was in the days when our semisavage ancestors wrested a hard-won living from a Nature which was no less uncompromising then than now. Electric lights, policemen, and universal suffrage will 
not make the philosopher endure his toothache with any more equanimity than he did in the days of old (1910: 2).

He believed that education must therefore include physical and mental aspects. Hygiene was a central part of this education, allowing children to overcome the ravages of nature. He indicated that education in hygiene would ideally be provided by parents but, due to ignorance or prejudice, parents were often unable to do this (1910: 8-9). As such, part of the work of teachers was to instruct parents in the practices of good hygiene. This idea is suggestive of a belief that the parents of Australia, and most particularly of Queensland, were failing in their duty to ensure the success of future white generations.

Whiteness was also taught through lessons in morality. Gardening was a form of ensuring civilised and moral behaviours in children. Through gardening children were to learn good habits in beautifying their surroundings and cultivate moral sensibilities (Wegner, 2010: 356). In addition, lessons in Civics and Morals, and later reading lessons framed by the Queensland School Readers, sought to inculcate a moral, British, and white identity.

Children were taught the correct way to be white through formal education. For white men, the solution was hard work. The role of tropical medicine in both inflaming and calming anxieties about the fate of the white race in the tropics cannot be overstated. This was a science which, for perhaps the first time, pathologised white bodies, including white, male, bodies. This was a science in which whiteness itself was questioned and tested (Bashford, 2000: 261). While initially tropical medicine held that Queensland's North was unfit for the white race as a whole, by the 1920s where was a general agreement that white men could prosper in the climate. This was in part due to the perceived restorative powers of manual labour (Henningham, 2001: 313). The nascent idea that physical labour could protect against the damaging effects of the harsh Queensland, particularly Northern, climate, had a clear impact on the development of reformatory practices.

\section{Reforming and protecting whiteness}

Queensland, as a colony and then a state, was a place in which whiteness was pathologised and questioned. This was never more significant than in the case of children who had in some way deviated from expected norms of behaviour. White lower class or working class identities can be and have been pathologised in relation to white middle-class identities (Hollingworth and Williams, 2009). In Queensland, tropical medicine offered an additional means through which whiteness itself was open to being pathologised. This situation, in which whiteness could be understood as on the precipice of degeneration, demanded a means through which white bodies could be trained, reformed, and transformed into useful citizens. There was never any expectation on the part of reformers that reformatory children would become members of the colonial elite. Instead, these children were prepared to participate in unskilled or semi-skilled farm labour.

The reformatory for boys housed children admitted for a broad range of offences. The legislation under which it was created provided for a system of industrial schools, created to house children of Carpenter's 'perishing classes', and reformatory schools, intended to house children who had committed crimes. However, this system did not come to exist. What instead occurred was that the new legal category, the 'neglected child', which was created under the Act in order to provide for children to be sent to industrial schools, was instead used to allow children who were convicted of no crime to be sentenced to the reformatory. In England, children convicted of industrial and 
reformatory schools had very different age and 'crime' profiles (Stack, 1994: 65-66). In Queensland these children were housed together.

Of the first one thousand boys admitted to the reformatory, 543 were neglected children, 353 were convicted of larceny, and the remainder had committed an array of other criminal offences (Queensland State Archives Item ID532416, Register - admissions, 1871). The charge of being a neglected child required that the parents of the child in question were unwilling or unable to look after them. This was therefore a group which was bound by social class just as they were (largely) bound by race. These were the white children of Queensland who were in danger or committing crimes, or who had actually already done so.

It is not possible to determine what the day to day experience of reformatory boys would have been like. However, the records provide a sense of what was prioritised in relation to the governance of the institution. From these records, and from newspaper reports, we can obtain an understanding of the type of training deemed appropriate for this broad array of children at risk. Formal education appears to have been a priority for both the Home Secretary's department, which operated the institution, and its first superintendent.

Through the reformatory's early history, from 1875 to at least 1919, reformatory boys received what was for the time an extensive formal education. This was not always delivered to an ideal standard - on the hulk Proserpine the superintendent was required to educate the boys himself. An 1879 news report stated that boys at the Hulk Proserpine were said to be generally healthy and to be doing well in their schoolwork despite the lack of a formal school teacher (The Telegraph, 1879: 2). However, this changed with the development of a more settled reformatory environment and by the time the boys arrived at Westbrook in 1900, a formal education was at the centre of reformation efforts. Boys were educated full-time - at five hours a day - until the age of twelve. They were educated for half of each school day from the ages of twelve to fourteen. Boys attending school spent an additional two hours per day on preparation for their lessons (Ryder, 1910: 1).

From 1900, at Westbrook, the reformatory school became associated with the existing state experimental farm. The presence of the reformatory institution in this environment was in keeping with practices in Victorian England which associated fresh air and rural atmospheres with good moral health and reformation (Ploszajska, 1994: 416). The Redhill farm school is the most famous British example of a reformatory school. This school was to serve as a type of antidote to the perceived degeneration associated with urban environments (Ploszajska, 1994: 418).

In 1906 Ernest Scriven, Undersecretary for Agriculture, wrote to the Secretary for Agriculture proposing that the Reformatory for Boys at Westbrook ought to be transferred to their department. It was his view that

[T]he system of education should be wholly of the country and savour as little as possible of the town or of book work. The corollary is that the training would be more effective under the supervision of this Department rather than the Home Secretary. Agricultural education is peculiarly the province of this Department, and if it be decided that the training of the Reformatory boys shall be wholly agricultural, there would seem to be no reason why this Department, which has trained men available for the purpose, 
men who could produce better results than teachers whose leanings may be in the

direction of the theoretical school, should not be entrusted with the work (1906: 1-2).

The type of education he proposed mirrors the type of lifestyle which was seen as preventing white men from experiencing racial degeneration in the tropics. It was based in hard physical labour, outdoor work, and the development of useful practical skills. This type of training was indeed carried out at Westbrook. A 1912 report prepared in response to a complaint made by a boy at what was then Westbrook Reformatory provides important insight into the work done by and for the boys. Mentioned in that report was a dairy herd, a piggery with twelve pigs, and gardening work. The report stated that no textile industries were carried on but that these could be introduced in the future (Office of the Visiting Justice, 1912: 6).

However, the institution was never given over to the Agricultural Department. Indeed, other than a single memorandum, there is no evidence in the archives to suggest that this was seriously considered. Aside from any potential legal difficulties, such a transfer would likely have precluded the reformatory carrying out its full function. Certainly hard physical labour - the work which was presumed to protect white men from racial degeneration - could have been supervised just as effectively by the Agricultural Department. So too could have the training, such as it was, in marketable skills have been carried out adequately under the auspices of that department.

However, classroom education remained important. In this way the methods of the reformatory during this early period of the twentieth century mirrored those of the rural schools which were created in Queensland from 1917 and which, Brady (2013) writes, sought to create a specifically Queensland yeoman class. These schools provided a regular primary education alongside instruction in various forms of trade and industry. Through providing an education that was demonstrably practical and useful, rural schools extended the educational career of many students in rural areas who would otherwise have left school as soon as legally permissible and been sent to work (Brady, 2013). Children at rural schools completed the ordinary first years of primary education. At the outset of their fifth year, they were to choose between an academic pathway, which would provide them with the opportunity to continue on to secondary education, or an agricultural pathway. This meant that children who opted to engage in agricultural education were prevented from attending ordinary secondary education and were instead prepared for a rural lifestyle (Brady, 2012: 91).

In both forms of institution physical labour and farm skills were taught alongside academic work. In both, agricultural skills became more important as the children grew older. The major difference - aside from the obvious fact that the reformatory children were incarcerated - was that children in rural schools had greater options and the ability to learn a broader range of skilled trade. The reformatory thus operated within the same broad ethos as rural schooling, viewing work on the land as a desirable future for the boys who came under its control. It provided, however, a greater emphasis on labour than on learning trades, preparing boys for less skilled farm work.

There is evidence to suggest that the reformatory was not always run as carefully or as successfully as rural schools. A 1916 visit by the Home Secretary resulted in significant criticism. The conditions were described as so bad that 'there was little if any chance of reforming the boys who were sent to [the reformatory at] Westbrook' (Telegraph, 1916: 3). This was not due to any lack of staff but instead to conditions under which the boys were left unclean and with worn out clothing and boots. The Home Secretary promised radical changes. As soon as the existing superintendent 
reached the retirement age of 65 , his services were dispensed with and he was replaced (Morning Bulletin, 1916: 4).

\section{Conclusion}

The reformatory is an extreme situation in which ideas of whiteness combined with issues related to class and deviance. It was primarily intended to provide what Mary Carpenter so famously deemed a 'useful education' and, as such, provides important insight into what was viewed as an education which could turn deviant boys into citizens. In particular, this reformatory demonstrates the means through which those most degraded of white Australians - the antipodean 'dangerous and perishing classes' were managed through a mixture of techniques associated with the protection of youthful whiteness and adult white men.

This case contributes to our understanding of the relationship between childhood and nation-building by demonstrating that, in the colonial context, only certain children could be constituted as future citizens and thus worthy of reform. It also highlights the extent to which the protection of whiteness in the youthful population was seen as essential to nation-building. The very whiteness of this institution is incongruent with the legislation under which it was governed. It is comprehensible primarily in the context of the fears of racial degeneration existent in Queensland at that time. These fears largely excluded Indigenous children from an institution to which they ought, under the governing legislation, to have been sentenced. The history of Indigenous Australian child removal is well known and it is undoubtedly the case that many Indigenous children would have been removed under the provisions of the Industrial and Reformatory Schools Act (1865). These children, however, appear in most cases to have been subject to a different type of program of reformation, outside of the very white space of the reformatory for boys. More research on the treatment of Indigenous children sentenced as neglected children, and the way in which this treatment compared to that meted out at Queensland's reformatory, is urgently needed. 


\section{Reference List}

Bashford A (2000) 'Is White Australia possible?' Race, colonialism and tropical medicine. Ethnic and Racial Studies 23(2): 248-271. DOI: 10.1080/014198700329042.

Brady T (2012) Nambour: the model rural school. Australian and International Journal of Rural Education 22(3): 87-99.

Brady TJ (2013) The Rural School Experiment: Creating a Queensland Yeoman. Doctor of Philosophy. Queensland University of Technology, Brisbane.

Butterworth L (2014) Reformatory School for Boys - Hulk Proserpine - Organisation - Find \& Connect - Queensland. Available at:

https://www.findandconnect.gov.au/ref/qld/biogs/QE00529b.htm\#related (accessed 25 August 2017).

Carden C (2018) A breakdown of reformatory education: Remembering Westbrook. History of Education Review 47(1).

Carpenter M (1851) Reformatory Schools for the children of the Perishing and Dangerous Classes, and for Juvenile Offenders. London: C. Gilpin, 5, Bishipsgate Street Without.

Elkington J (1907) Health in the School. Blackie's Library of Pedagogics. London: Blackie and Son.

Elkington J (1910) School Hygiene. In: School Committees' Association, Brisbane, 21 November 1910.

Henningham N (2001) 'Hats off, gentlemen, to our Australian Mothers!' Representations of white femininity in north queensland in the early twentieth century. Australian Historical Studies 32(117): 311-321. DOI: 10.1080/10314610108596167.

Hollingworth S and Williams K (2009) Constructions of the working-class 'Other' among urban, white, middle-class youth: 'chavs', subculture and the valuing of education. Journal of Youth Studies 12(5): 467-482. DOI: 10.1080/13676260903081673.

Hurt J (1984) Reformatory and industrial schools before 1933. History of Education 13(1): 45-58. DOI: 10.1080/0046760840130104.

Lynch G (2014) Saving the child for the sake of the nation: Moral framing and the civic, moral and religious redemption of children. American Journal of Cultural Sociology 2(2): 165-196. DOI: 10.1057\%2Fajcs.2014.5.

Morning Bulletin (1916) Queensland News. 15 July. Rockhampton.

Office of the Visiting Justice (1912) Reformatories Westbrook Inquiry. Report.

Ploszajska T (1994) Moral landscapes and manipulated spaces: gender, class and space in Victorian reformatory schools. Journal of Historical Geography 20(4): 413-429.

Queensland (1865) Industrial and Reformatory Schools Act. Available at: http://nla.gov.au/nla.obj54468084 (accessed 12 September 2017).

Queensland State Archives Item ID532416, Register - admissions (1871) Queensland State Archives. Available at:

http://www.archivessearch.qld.gov.au/Search/ItemDetails.aspx?ltemld=532416. 
Robinson S and Paten J (2008) The question of genocide and Indigenous child removal: the colonial Australian context. Journal of Genocide Research 10(4): 501-518. DOI:

10.1080/14623520802447818.

Robinson S and Wilson E (2008) Preserving the Traditions of a 'great race': youth and national character in Queensland, 1859-1918. Journal of the Royal Australian Historical Society 94(2): 166-185.

Roe M (1981) Elkington, John Simeon Colebrook (1871-1955). In: Australian Dictionary of Biography. Canberra: National Centre of Biography, Australian National University. Available at: http://adb.anu.edu.au/biography/elkington-john-simeon-colebrook-6101 (accessed 6 September 2017).

Ryder W (1910) Report of the Under Secretary, Home Secretary's Department, Upon the Industrial and Reformatory Schools Established in Queensland. Brisbane: Queensland Parliament.

Savige A (1993) 'Naughty' Boys: The Education of Reformatory School Boys at Lytton 1881-1899. Journal of the Royal Historical Society of Queensland 15(1): 33-48.

Scriven E (1906) Under Secretary, Department of Agriculture and Stock to The Secretary for Agriculture.

Smith C (1998) INCREDIBLE HULKS: SHIP SCHOOLS AND THE REFORMATORY MOVEMENT. Emotional and Behavioural Difficulties 3(1): 20-24. DOI: 10.1080/1363275980030104.

Stack JA (1994) Reformatory and industrial schools and the decline of child imprisonment in midVictorian England and Wales. History of Education 23(1): 59-73. DOI: 10.1080/0046760940230104.

Swain S (2016) Enshrined in Law: Legislative Justifications for the Removal of Indigenous and NonIndigenous Children in Colonial and Post-Colonial Australia. Australian Historical Studies 47(2): 191-208. DOI: 10.1080/1031461X.2016.1153119.

Telegraph (1916) Westbrook Reformatory. Minister's Criticism. 18 July. Brisbane.

The Brisbane Courier (1865) 9 June. Brisbane.

The Telegraph (1879) Reformatory Hulk for Boys. 19 August. Brisbane.

Watts R (2001) Mary Carpenter and India: Enlightened liberalism or condescending imperialism? Paedagogica Historica 37(1): 193-210. DOI: 10.1080/0030923010370112.

Wegner J (2010) Why garden? Gardening on mining fields in the dry tropics of Queensland, 1860 to 1960. Journal of Australian Studies 34(3): 347-361. DOI: 10.1080/14443058.2010.498333. 